\title{
Religion and Environment: Evaluating the Role of Religions inthe Nigerian Environment
}

\author{
${ }^{1}$ AYO FATUBARIN PhD, ${ }^{2}$ David O. Alabi PhD \\ Department of Biological Sciences, Joseph Ayo Babalola University, Ikeji-Arakeji, Osun State \\ Department of Philosophy and Religious Studies, Joseph Ayo Babalola University, Ikeji- Arakeji, Osun State
}

\begin{abstract}
Religion and Environment are presented as vital aspects of the life of a nation. This is because they both affect the life of the people of the nation. Religion has to do with the spirit of humankind as well as the god he believes in. Religions come into being as a result of the search by humankind to have a link between him and his god. In Nigeria, Christianity and Islamic religions are the two prominent religions, even though a large number of other traditional religions exist among the people of diverse tribes. Five major environments are recognized, with the natural environment being in the prominence for meeting both the basic needs of people in other environments besides providing a large number of other useful services. It came into being with the existence of the planet earth. Other environments such as the socio-economic environment, the built environment and the political/governmental environments, are the creations of humankind, made possible by his unique endowments. The spiritual environment is the environment within which the spirit being of humankind operates, in the process of accessing the Almighty God. Religion influences all the diverse environments in diverse ways. Christian religion in particular, teaches about the consequences of greed, corruption, violence and injustice in the environment. It also makes it clear to humankind that the Almighty God frowns against them. Instances abound in the bible where He has punished them. It therefore behooves humankind, to remember that he will one day give an accountof his actions in the environment within the planet earth, to his maker - the Almighty God.
\end{abstract}

Key Words: $\quad$ Religion, Environment, Humankind, Almighty God, Sustainability.

\section{Introduction}

Environment has become a major issue in the world, as a result of its importance as a major factor not only in development of nations, but also in the all-important issue of sustainability. So important is environment that Adelegan (2009), quoted a reknowned Nigerian economist Pius Okigbo, as saying, that nations aspiring for outstanding success in the $21^{\text {st }}$ century, must intensity effort in deploying the valuable tool of knowledge, to explore the potentials of their natural environment, to create the wealth they will need in the new century. It is therefore important that no aspect of the national life of the country is left behind, in the bid to have an in-depth understanding of environment. This is with a view to knowing where the "shoe is pinching" and with a view to contributing their own quota. This is particularly so with climate change, a global phenomenon that has been described as the greatest possible threat to the continuing existence of the planet earth (Foley, 1991). It is therefore not surprising that religion a vital aspect of the national life of a country like Nigeria, is not left behind. This is particularly so because in Nigeria, the people are claimed to be religious and from amongthe people, national as well as worldreknowned religious leaders can be counted in large numbers.

There is therefore the need for all believers of the diverse religions and all people who ply their trade in religion, to have an in depth knowledge of what truly religion is and what environment is. In particular, people should understand their importance and the way they interact and through such interactions influence what goes on in each of them. This precisely, is what this paper has set out to achieve.

\section{Religion}

Religion is a unique institution in the society that cuts across human race. It is a peculiarity of humankind, made possible by his unique nature as a three-fold being of the physical, the social and the spiritual (Adeboye, 2012). Humankind as scienceswould make us to believe is a product of evolution (Fatubarin, 2008). He is claimed to have in the process of organic evolution, passed through different forms of humankind in such forms as Dryopithecus,Australopithecus, Homo habilis and Homo erectus, among others (Fatubarin, 2008). All these forms of humankind preceded the modern man, known as Homo sapiens, also known as the perfect man.Ofall the diverse forms of humankind, only Homo sapiens developed to the stage of spiritual evolution that made him to believe in the life of the spirit and in the existence of one or more gods, as the definition of religion above implies. It is the modern man Homo sapiens, which practised religion. It is he who believes that though other gods may exist, there is only one Almighty God, the Supreme Being. 
It is also widely believed that the other gods are creations of humankind, which have become divinities that are used to gain access to the Supreme Being. The Christiansbelieve that He can only be accessed rightly through Jesus Christ, who in the holy Bible claims of Himself that He is the way and that no one reaches the father, except through him (cf. Jn. 14:6). The Muslims of Islamic religion believe in accessing the Almighty God, who they call Almighty Allah, through His prophet Mohammed. Among theYoruba people, some adherents of some traditional religions such asOgun,(Yoruba god of iron), Ifa, (The Yoruba god of oracular activities), Oya, (a water goddess of River Oya), Sango,(the Yoruba god of thunder) andOsun (a river goddess of River Osun) among others, believe that they are accessing this same Almighty God, through these lesser gods and divinities. In essence therefore, the diversity in accessing this Supreme Being, has led to the emergence of different religions in different parts of the world, with the adherents of these religions doing much to win souls for the Almighty God.

In Nigeria for example, through several decades of interacting with the diverse religions, two principal religions have emerged. These are the Christian and Islamic religions. However, a number of other religions still exist in the country. In this paper however, emphasis will be placed specially on the Christian religion in shedding light on how religion interplays with the environment in diverse ways. Occasionally, reference will be made to any other religion, where this becomes necessary to further clarify any issue on environment.

The Christian religion not only recognizes that humankind has a spiritual component; it recognizes that this spiritual component is made possible by the Almighty God, who created him in His likeness (cf. Gen. 1:2628).The religion believes that the Almighty God is a spiritual being and that He can best be worshipped in truth and in spirit (cf. Jn. 4:24). Christian religion not only makes people to acknowledge the existence of the Almighty God and His supremacy over other gods, it also makes people to acknowledge the trinity, comprising of God the Father, the Son and the Holy Spirit. It makes people to recognize that people should obey His commandments set out in the Scripture and what to do to seek forgiveness of their sins. It teaches people how to access the Almighty God through prayers, fasting, reading of the Holy Bible, meditating on the word, making restitution (among others). It also teaches people to love themselves, love others as they love themselves and love the Almighty God.

Religion in essence has to do with humankind. It has to do with a Supreme Being - the Almighty God. It has to do with the spiritual nature of humankind and that of God. It has to do with conscience. It has to do with giving accounts of one's deeds on earth, sooner or later, before the God. The Christian religion also sheds further light on the expectations of the God from humankind, whom He has conferred with dominion over His creations, which today occupy the so-called planet earth. This religion tells us about the Almighty God, who hates disobedience, greed, corruption and violence. Genesis chapter 3 tells us that it was disobedience that made God to send out Adam and Eve from the Garden of Eden.It was greed that made God punish that King Saul whom He gave directive, to go and slaughter all people and animals at Amalek(cf. 1 Sam. 15). It was greed that made the leprosy of Naman to stick to Gehazi the servant of Elisha for life(2 Kgs. 5:20-27). The Almighty God destroyed the first world at the time of Noah, as a result of corruption and violence (Gen. 6:11, 12 \& 13).Later in this paper, it will become clearer how all these sins which the Christian religion has foreseen play out in the environment and the diverse consequences humankind is facing as a result of these sins against the environment.

\section{The Environment}

The term environment when defined as "the surrounding of an organism in the place where it lives" (Fatubarin, 2009a), is as it is, an open-ended definition, which makes the concept of environment applicable to more than one type of environment. These environments to which the definition above applies are:

i. The natural environment

ii. The socio-economic environment

iii. The built environment

iv. The political/governmental environment

v. The spiritual environment.

All these environments by their nature, constitute the surroundings of organisms (plants, animals and microbes, with human beings inclusive), in the places where they live. Each of these environments contains some other non-living things besides the organisms that inhabit them. In each of them, certain interactions occur, that affect the life of the organisms living in them. Besides, these environments are in constant interactions with themselves, with the result that these interactions have implication on the overall sustainability of all the environments. The implications of this is that, in whatever environment one is actively engaged in, one must be conscious of the need to factor into one's reckoning, the welfare of other environments, to assure the sustainability of that environment of interest to one.

To fully grasp the issues being canvassed in the paragraph above, it is imperative to have a thorough understanding of the various environments, their importance, their interactions and the implications of these 
interactions on the sustainability of the natural environment, which is what most people think or talk about, whenever the environment is being discussed.

\section{The Natural Environment}

To the environmentalists, the term environment means "the surrounding of an organism in the place where it lives" (Fatubarin, 2009a). By implication or extension, the term environment is applicable to all those components of the localities in which living things (plants, animals, microbes and human beings) are found and with which these living things interact and through such interactions, sustain their life. The environment this definition is referring to, is also known as the natural environment, as well as the biological environment (Adesiyan, 2005; Fatubarin, 2009b). It can also as well be termed the ecological environment. This is because environment is a major concept of ecology, a course in which the natural environment is placed in its proper perspective. As the natural environment, it is the portion of the earth, in which all tangible and intangible things that are found in the planet earth exist and combine in their actions to make the earth what it is. As Bellamy (2007) rightly deposed that the natural environment includes such things as air, water, soil, light, temperature and the living things. Gilpin (1976) also submits that the environment also includes such things as geographical location, climatic conditions and the terrain, which is the topography. As the biological environment, it is the portion of the earth, where all activities essential to life take place. It is also the portion of the earth in which diverse interactions in which living things (including humankind) participate, occur.

This natural environment is not a creation of humankind. It has been in the planet earth, before humankind started evolving in the planet earth. It can be assumed that this is the environment the Almighty God put in place on the six days of creation, before He rested on the seventh day (Genesis 1:

The natural environment provides for living organisms, certain necessities of life, which include the following:

a. Sunlight:-A climatic factor, which provides the planet earth with the light that, makes visibility possible on earth.

b. Sunlight also has solar energy, the energy that makes photosynthesis possible in plants, a process through which plants obtain their food and through which products of commercial importance, such as woods, fruits, seeds, drugs et cetera are got. The by-product of photosynthesis is oxygen, which helps in purifying the air of the environment.

c. Sunlight also makes all other forms of energy possible in the planet earth. Such energy forms include thermal energy, which accounts for the warmth and heat on earth. No wonder then that sunlight is regarded as the ultimate source of energy on earth (Fatubarin, 2009c).

d. Rainfall, a major source of water in the tropics, is also a climatic factor that makes water available in the planet earth.

e. Temperature, a climatic factor, makes possible appropriate heat energy needed for the metabolism of all living things, including human beings.

f. The air of the atmosphere contains oxygen, which makes aerobic respiration possible in living organisms. This is a metabolic process of importance in the survival of most living things.

g. The carbon dioxide of the atmosphere makes possible photosynthesis in the plants. It is a raw material in the process of photosynthesis.

h. The water of the environment provides the water needed for many living processes in living organisms. Water makes photosynthesis possible in plants. It makes a large number of other metabolic processes possible in all living things. It also serves as the aquatic environment where aquatic organisms live. Water also has a large number of important uses for human beings, in such things as domestic uses, industrial uses, commercial uses, scientific uses and agricultural uses, among several others (Fatubarin, 2003).

i. The lands, soils, rocks, minerals and mineral ores that are components of the abiotic environment, are parts of the natural resources around which several agricultural, commercial, industrial and scientific activities of human beings revolve. The activities of the built environment for instance, thrive on the existence of lands, trees, among other requirements.

j. The plants and animals, which constitute the biota of the environment, are not only important as natural resources of the environment; they also provide a large number of benefits to human beings.

\section{Other Environments}

It is the modern man that has given rise to other environments, which today are sharpening the course of the natural environment and are giving environmentalists and people with discerning minds, cause for concern about the natural environment. These other environments include the Socio-Economic Environment, the Built Environment and the Political/Governmental Environment. The only other environment, which is a new addition to the previously hitherto well known and widely recognized environment, is theSpiritual 


\section{Environment.}

These other environments also fit the classical definition of environment "as the surrounding of living things, in which interactions are occurring, that affect the life of the living organisms". The only difference is that the living things of the natural environment, now have the humankind in the form of modern man, playing greater roles in them, than have hitherto been played by them. Besides, the advent of the modern man in the environment has now altered the stable equilibrium existing between the living things, including that between the primitive humankind and other components of the environment. The other living things that constitute the biodiversity of the natural environment are also affected adversely by the advent of this new species, Homo sapiens, the perfect man and the king of all species.

The modern man is not only taking more than his own fair share of the resources of the natural environment, he is also polluting the environment, degrading it and causing much loss to the biodiversity of the planet earth. It is the concern for the unguarded activities of the modern man in the environment, that have given rise to concepts such as sustainability, loss of biodiversity, conservation, land degradation, environmental virtues, among others. All of these are expressing genuine concern of environmentalists about the welfare of the living and non living components of the planet earth and the very future of the planet. This is particular so, in the light of the current global challenge of climate change, which has been alluded to in some quarters as "the greatest challenge ever faced collectively by humankind in the planet earth" (Foley, 1991).

\section{Features of the Other Environments}

Earlier on in this write up, the natural environment was discussed along with its importance. Below in this section of the paper, other environments are also discussed along with their importance.

\section{The Socio-Economic Environment and Its Importance}

This is an environment which is often discussed simply as the social environment, as well as the economic or business environment. Bellamy (2007) captures this by defining the social environment as that environment in which interactions are occurring between the individuals of the species. The socio-economic environment is the environment in which all professionals interact in the process of going about their professions. It is the interactions in this environment that determine the gross domestic product (GDP) of a country. It is the environment that determines the social stratification of the people of a country, the level of poverty, the quality of social services, the quality of infrastructural development and other socio-economic indices of development in a country.

\section{The Built Environment}

This according to Bellamy (2007) is an environment that is well planned and built, providing congenial conditions for the people to operate in. Oriye(2008), also noted that the built environment is an area of the earth's surface, that has been modified by human activities. The built environment is therefore an environment where human activities in such things as town planning, land surveys, quantity surveys, architectural designs, building and estate management occur. It also features different engineering works, such as civil, electrical, and mechanical among others.

The built environment is the environment that provides human beings with places for human habitation, places that constitute shelter, a primary necessity of life (Fatubarin, 2013). It is the environment that interacts with the socio-economic environment, to determine the quality of life in a country.

\section{The Political/Governmental Environment}

The political/governmental environment is the environment which involves politics, governance, policies and such other actions of regulatory authorities that lead to legislations, laws, directives and judgments and other activities that regulate human behavior in a community. This is the environment in which the politicians, technocrats, civil servants, legislature and judiciary, are involved. This environment has the people involved in it sheltered within the built environment and the people are involved in activities that sharpen the direction of activities not only in the built environment, but also those of the socio-economic environment as well as the natural environment. It is an environment that has a powerful influence not only on the stability of all other environments, but also on their sustainability.

\section{The Spiritual Environment}

This is an extra-terrestrial environment, which operates beyond the realm of the planet earth. It is an environment people easily forget about or gloss over. This is because it exists in the sub-conscious realm. It is the environment that has given birth to religions in the world. It is the environment in which the Supreme Being and "the holy" and "the unholy" spiritual beings, interact with human beings at the sub-conscious level, to 
determine and influence the activities of human beings in the planet earth. It is the environment which can only be seen by people who are blessed with spiritual eyes, or who have acquired it by some powers.

This is an environment from which people who believe in the Supreme Being obtain inspirations, directives and guidance, that enable them perform miracles and such other supernatural deeds, that shapes their lives and those of other people. It is also the environment from which adherents of the "unholy spirits" obtain their own inspirations, directives and guidance, that make them carry out unholy deeds that affect them and other people adversely.

This spiritual environment has been there, since human beings started evolving on earth. However, it is the time the evolution of humankind led to spiritual development of humankind that he started operating actively in this spiritual environment.

A ready example of the interactions that occur within the spiritual environment which influence occurrences at the physical realm on earth, is that between the Supreme Being and Satan, which influenced those unpleasant experiences Job had at the hand of Satan (Job 1:6-12). It must also be acknowledged that most human beings whether religious or non-religious, do recognize at one stage or another in their life, that there exists a Supreme Being that must be acknowledged, feared and obeyed in all admonitions ascribed to Him. This Supreme Being abhors corruption and violence. The Bible in Genesis 6:11,12 and 13, claims that it is the duo of corruption and violence, that brought about the destruction of the first world at the time of Noah. It can be assumed that this Supreme Being will not condone corruption in any of the environments in any form in which it is manifested.

\section{The Prominence of the Natural Environment}

The natural environment is usually accorded a pride of place among other environments. This is so because it is about the best known of all the environments. It is the environment that engages the attention of environmentalists. It came into being before even humankind, who created other environments. Besides these facts however, are a number of others, which include the fact that it is this environment that helps in sustaining life through the provision of the basic necessities of life in the forms of food, shelter and clothing, with these being in addition to other services earlier listed for it in (a) to (j) as areas of its importance.

The natural environment besides its importance as an environment, also contributes largely to the activities of humankind in other environments. These contributions are outlined below:

The natural environment helps to sustain the socio-economic environment by the following:

i. Providing the soil in which most plants are anchored and from which they derive the bulk of the material needs, thereby fostering the agricultural forestry and horticultural activities of man that are anchored majorly on plants.

ii. Providing the water which has a large number of uses for human beings in such things as domestic uses, industrial uses, commercial uses, scientific uses and agricultural uses, among several others.

iii. Providing lands, soils, rocks, mineral ores and solid minerals, as components of the abiotic environment and as parts of the natural resources around which several agricultural, commercial, industrial and scientific activities of human beings revolve.

iv. The plants, animals and microbes, which constitute the biota of the natural environment, are not only important as natural resources of the natural environment, but also provide a large number of benefits to human beings as the biodiversity of the natural environment.

Similarly, the natural environment helps to sustain the built environment by:

i. Providing the material requirements for putting up the structure of buildings, in such things as rock aggregates, soil materials and water.

ii. Other material needs of buildings in form of planks, asbestos and similar materials are also got from the natural environment.

iii. Structural materials such as iron rods, nails and other metallic materials used in different aspects of building construction, are usually got from the mineral ores present as part of the topography of natural environments.

iv. Similarly, the plant materials come in handy in living forms as ornamentals used in landscaping the buildings of the built environment and those used in creating green belts and zones within the built environment.

The natural environment also benefits the spiritual environment by many of its components such as oxygen, solar energy, water and plants making living possible for human beings. This is through their sustaining respiration, feeding, housing, clothing and energy needs of human beings. The importance of this is that, only the living can have interactions with the spiritual realm that operates in the spiritual environment. 


\section{Religion and Its Roles within the Environments}

As earlier noted, religion has to do with the environment/ environments, through the activities of humankind, the only living organism, endowed with a spiritual being, which enables him to put in place the institution of religion. The various roles of religion particularly the Christian religion in the diverse environments are discussed below.

\section{Religion and Its Roles in the Natural Environment}

The Christian religion makes us appreciate the use of palm fronds in Christian religious ceremonies. One example which cuts across virtually all sects of the Christian religion is the use of palm fronds a product of natural environment, on Palm Sundays, to mark the symbolic triumphant entry of Jesus into Jerusalem (cf. Mat. 21; Mk. 11; Lk.19:28-48). The palm fronds symbolize his victory in His mission on earth and the carriers of the palm fronds; represent people who identify with Him. The palm fronds are also in use for decorating churches during harvest celebrations. Incidentally, some masquerades do wear palm fronds as part of their paraphernalia in Yorubaland. This is true of the aladoko masquerade. The Aladoko masquerade is a species of masquerade among the Yoruba people in the South western part of Nigeria. The Ogun worshippers also use the palm fronds in decorating their shrines and workshops, during the season when Ogun, the god of iron is worshipped in Yorubaland. The members of some Christian religion sects also have Prayer Mountains, which they occasionally frequent, to offer prayers. This is a practice copied from Jesus Christ, who while on His mission on earth did occasionally visit some mountains for private prayers, sometimes with His closest disciples. Nowadays, these so-called prayer mountains need not be mountainous. They may be scheduled prayer areas on level grounds.

Some sects of Christian religion still encourage special dedication of some water bodies for their healing powers. An example of such water bodies is Omi Ariran, a divinely sanctified healing water situated at the gate of Joseph Ayo Babalola University,IkejiArakeji, Osun state. The gently flowing perennial stream is believed to have been blessed and specially dedicated by Joseph Ayo Babalola, the patriarch of Christ Apostolic Church (CAC) world-wide. Similar water bodies with healing powers probably exist in many other places. It must also be mentioned that some religious sects, dedicate certain forests as sacred forests and sacred groves. The Yoruba people have such as Igbo Oro, Igbo Igbale, Ojuboorisa and the likes. Late D. O. Fagunwa also made two of such forests in Ile-Oluji, Ondo State, Nigeria (Igbo Olodumare-The Forest of Olodumare) and Ogboju Ode NinuIgbo Irunmole-The Forest of a Thousand Demons) titles of some his monumental Yoruba novels. The Christian religious culture of visiting Prayer Mountains was witnessed in the ministry of Jesus Christ as earlier mentioned. Similarly, the culture of bathing in water most probably started withNaman the Leper (2 Kgs. 5). Moses while on a visit to the mountain to receive the commandments, also stood on a holy land, where fire was raging and the bush on the land was not consumed (Exo. 3).

In the days of Noah, God destroyed the first world with water, as a result of corruption and violence (Gen. 6-8). Today, theenvironment is being corrupted and violated by diverse forms of violence, all of which have now resulted in ecological challenges as well as sociological challenges, which are discussed later in this paper. The natural environment is therefore presently under severe threats of a combination of climate change, global warming, land degradation, environmental pollution, noise pollution, with the result that its sustainability is being threatened as a result of actions reflecting declining environmental values among the people. Even simple hygiene, for which Moses was advised about while he was invited to meet with God on a mountain with some representatives of the people of Israel (cf. Exo. 19:7-24), is now being handled with levity.

\section{Religion and Its Role in the Socio-Economic Environment}

Religion has influenced to a great extent the cultural, sociological as well as economic and business activities in the socio-economic environment. One such activity among the Christians is the payment of tithes. This is a command of God (cf. Mal. 3:10-13) to keep off devourers from one's businesses or earnings. Governments at all levels are also presently demanding taxes-a cultureenforced in the Bible (cf. Mat.22:15-21), which has led to the saying, "give unto Caesar, what is Caesar's". Religions have influenced modes of dressing, within some Christian sects, such as Cherubim and Seraphim and Celestials among the Christian sects, wearing white garments with all sorts of attachments, as were built for worshippers of old in the Bible (cf. Exo. 28-29). Religion has also brought about pilgrimages to Jerusalem in Israel, Meccaby the Muslims, and some sacred lands by other religious adherents. Religion also brought about training and education of people. This is one area Christianity has impacted the people in many parts of the world, since the colonial days, with the missionaries coming with a dual mandate of converting the people and educating them. Religion has also impacted the marriage culture of believers. For instance, Christianity preaches monogamy in marriage andIslam upholds monogamy but if you are able to marry more than one with enough provision, you can. Both Christianity and Islam abhor divorce in human society for the sake of maintaining peace and reconciliation in the environment. 


\section{Religion and Its Role in the Built Environment}

Religion has also impacted the built environment in diverse ways. As earlier noted, it has led to creation of "Prayer Mountains" among some Christian sects and special prayer grounds for SalahandJumat services, among the Muslims.It has also created shrines and diverse sacred forests and groves among some other worshippers of some traditional religions. This is the case with Osun grove in Osogbo, the Osun State capital. The Christians in the past, usually have some large grounds with many trees with huge canopies, where they usually celebrate the Galilee services, a Christian ceremony based on the biblical account of the disciples meeting Jesus Christ in Galilee, after His resurrection.

In many places the buildings used by adherents of certain religions, reflect such religions. For instance among the Christians, the buildings usually have a giant cross placed in conspicuous place, with the buildings painted in many places with a deep grey colour, called cathedral colour. The churches may also have a giant tolling bell erected near them. The Muslims on the other hand, usually have their mosques patterned after those in the Middle East. They may display crescent and star as their symbols. In many places, it is usual to have the church buildings and manse well landscaped with different ornamentals.

In recent times, as a result of some attempt by some sects of both the Christian and Islamic religions, noise pollution is becoming rampart in places where the believers of these religions worship. This as a result of the loud speakers they mount on their buildings and as a result of several long hours of prayers, ministration, praise worship and the like. Equally noticeable in Nigeria in recent times, is the establishment of numerous religious settlements, where worshippers move to on certain days of the month for worship. Such religious establishments, which have auditorium of large dimensions, several worship places and residential buildings, are now common sight along Ibadan-Lagos express road in Nigeria.

\section{Religion and Its Role in Political/Governmental Environment}

There can be no doubt about the fact that leaders of many religious groups wield much influence over many individuals in politics and government. This is particularly so, if such religious leaders have attained national and global prominence. It is also true, if such leaders are endowed with special gifts of prophesy, miracles, ministration and prayers. As a mark of respect to the two main religions and more importantly,patronage to members of political parties in government, virtually all governments at the federal, state and local government levels, do sponsor a large number of people on annual pilgrimages to Jerusalem for Christians and Mecca for the Muslims.

In Nigeria, for example, the policy of freedom of worship is upheld in all places. Similarly, the policy of nondiscrimination of religions is upheld in all government establishments.

\section{Religion and Its Role in the Spiritual Environment}

As earlier noted, religion is the form humankind uses to openly manifest his spiritual being. Even though, this spiritual being of every kind is manifested in all issues bordering on conscience and decisions that affect destiny. All these issues, make humankind access the spiritual environment where there are angels to link one with the Almighty God and there are devilish spiritual beings that link humankind with Satan and his cohorts, as the case may be.

Christians access the spiritual environment to reach the Almighty God, through prayers, fasting, reading and meditating in the word of God and through kind words, kind deeds and kind thoughts. Since reaching the Almighty God formally has its protocol, believers of the Christian faith, usually start with praise and worship, followed by thanksgiving and then petition to the Almighty God. The Muslims of the Islamic faith also believe in prayers, thanksgiving, fasting and giving, what they call sakat.

\section{Concluding Remarks}

It must be emphasized that religion has a role to play in the diverse environments, particularly in stemming the diverse challenges of the diverse environments. These challenges as earlier noted include the ecological challenges as well as the sociological challenges.

The ecological challenges include such issues as climate change and associated challenges of greenhouse effects, ozone-layer depletion and global warming and environmental pollution and associated issues of gas flaring in some countries of the world, such as Nigeria. There are also challenges bordering on criminal dumping of toxic wastes as has occurred at a time in Koko in Nigeria and poor handling of municipal wastes in many developing countries. Others include massive loss of biodiversity in many third world countries such as those in Africa and the associated issues of deforestation, poaching of wildlife species, massive land clearing and use of weapons of wars that are threatening the existence of wildlife species in war-torn countries. There are other ecological challenges in such things as illegal burning and abuse of fire in many places, where fires are set into the vegetation as a cheap means of clearing bush, preparatory for land cultivation and using such fires to drive out wildlife species from their hiding places among the bush and from holes. 
The sociological challenges are those challenges that are arising among the people of developing nations of the world that are compounding the other group of challenges earlier discussed under the ecological challenges. They are challenges that border on poor leadership, bad governance, poverty, political corruption and greed. It is these challenges that are reflecting in poor attitude of leaders to issues of the environment and absence of laws that will regulate activities of people in the environment. Poverty is also making people to resort to use of fire woods and charcoal got from the vegetation within their locality. There is also massive corruption that is encouraging illegal felling of timber species, illegal mining and activities of oil prospecting companies causing pollution of the environment through crude oil spillage, without facing appropriate sanctions. There are also illegal siphoning of crude oil, pipeline vandalization and illegal refining of crude oil in a way that is destroying the environment within the vicinity of such refineries.

The above-discussed challenges are challenges within the other environments-the man-made environments, whose effects are felt not only in these environments, but also in the natural environments. In many developing countries, even those of them that are generating much funds from the natural environments, are not doing enough to see to the sustainability of their natural environments. For now, all one can say is that unless and until our governments in developing countries of the world appreciate the importance of the environments and give them the appropriate attention they deserve in policy issues, the sustainability of our natural environment will still be under much pressure from the man-made environments-their environments. This is an area the religious groups can come in and assist with proper sensitization of their members on these environmental issues with a view to stopping them or at least mitigate their effects.

Humankind has over a period of time in the planet earth, evolved some values which are those things of life adjudged by him to be important in attaining good success in life, both for oneself, the community and the nation. These values are to transform our mindset, our attitudes and our life styles (Kaushik and Kaushik, 2008). Fatubarin (in press), listed these values to include spiritual values, family values, societal values, national values and personality values. Other listed by him include ethical values, aesthetic values and environmental values. If humankind can imbibe these values, and bring them to bear on the dealings in all the diverse environments, there will not be any concern about the sustainability of the natural environments and the man-made environments. These values are like all other good things of life available in the spiritual environment for all human beings as spiritual beings, to access. Only those imbued with the religious wherewithal to access these values do benefit from them. Similarly, only leaders that possess the religious wherewithal to access these values, make their nations access these values, without which no nation can guarantee sustainability of not only their environments, but also the overall development of such nations.

As earlier on remarked, religion is about the people. It is about their God. It is about sustainability. It is about righteousness. It is about holiness. It is about fear of God. It is about giving accounts of whattranspired on earth, later in the world beyond. It therefore behooves humankind to remember that as religion reminds him about that sooner or later, he will give an account of all such things as greed, corruption, violence and other forms of injustice, he perpetrates in the environment, before the Almighty God, who created him and gave him dominion over the environment entrusted to him to nurture and sustain for ever. Humankind will account before his Creator, the extent to which he has nurtured and sustain the environment of the planet earth and how responsibly he has exercised the dominion conferred on him, on the creations with which he is cohabiting in the environment.

\section{References}

[1]. Adeboye, E. A (2012),KeynoteAddressat the 2012 Annual Convention of Redeemed Christian Church of God on theTheme of Signs and Wonders.

[2]. Adelagan, A (2009), Life in the $21^{\text {st }}$ Century: Maximizing Your Potentials to Prosper. Lecture delivered at the special convocation week of Joseph Ayo Babalola University, IkejiArakeji, 6 .

[3]. Adesiyan S. A. (2005), Man and His Biological Environment.Ibadan: IbadanUniversityPress, 196.

[4]. Bellamy, P. (2007), Dictionary of Environment. EPP Books Series Nigeria Ltd., 483.

[5]. Fatubarin, A. (2003), Applied Biology. Ilorin: Decency Printers and Stationeries Ltd., 124.

[6]. Fatubarin, A. (2008). Evolution. Ilesa: Keynotes Publishers Ltd., 81.

[7]. Fatubarin, A. (2009a). Tropical Ecology.Ilesa: Keynotes Publishers Ltd., 127.

[8]. Fatubarin, A. (2009b). Man and His Environment.Ilesa: Keynotes Publishers Ltd., 123.

[9]. Fatubarin, A (2009c). Ecosystem Ecology.Ilesa: Keynotes Publishers Ltd., 94

[10]. Fatubarin, A (2013). Economic Botany.Ilesa: Keynotes Publishers Ltd., 131.

[11]. Foley, G. (1991). Global Warming: Who is taking the heat? London: Patos Publishers Ltd., 104.

[12]. Gilpin, A. (1976). Dictionary of Environmental Terms. Routledge\&Kegan Paul Ltd. 191.

[13]. Kaushik, A \&Kaushik, C.P (2008). Perspectives in Environmental Studies. New Delhi: New Age International Publishers Ltd., 309.

[14]. Oriye S. O (2008). The Impact of Urban Expansion on the Land Use of Ado-Ekiti, Nigeria.(Unpublished PhD Thesis). University of Ado-Ekiti. 287. 